検查法

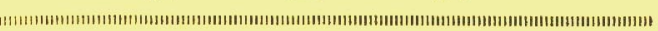

\title{
Sugar water test
}

発作性夜間血色素尿症 (以下 PNH と略す) は明け方に血色素尿を呈する特異な後天性溶血 性貧血であるが，その原因については不明な点 が多い。現在までに得られた諸成績のらちで溶 血と直接関係すると考只られるのは赤血球の膜 に異常があり，赤血球膜の Acetylcholine esterase 活性の低下していること, 電顕的に赤血球 膜の構造異常がみられること, 補体が直接赤血 球について溶血を䓯起することなどである。

本症の診断にあたっては Ham の test, Crosby の Thrombin test があり, Screening test と しては, Hegglin-Maier の熱試験が用いられて いたが，手技が頻雑であったり判定に時間がか。 かるなどの難点があったためか一般㭘査室では あまり行なわ机ていない. 1966 年 Hartmann ら1により簡便で PNH に特異的であるといわ れる Sugar water test および Sucrose hemolysis test が紹介された。 Sugar water test はScreening test で, この方法で溶血がみられたら さらに Sucrose hemolysis test を行ない溶血の 有無を判定する。

本試験の理論的根拠は充分明らかでないが， PNH 患者赤血球は直接補体と結合し且つ極 微量の補体の附着によっても溶血することが知 られている2)。一方蔗糖溶液などの低イオン強 度の溶液中では赤血球は補体により容易に coating されるため, 他の正常または患者赤血球 に比し溶血し易いと考えられている3 . 以下本 試験の手技と臨床的意義につき述べる。

\section{<検査方法（図 1) >}

1. Sugar water test:( 1 ) $10 \mathrm{~g}$ の市販の仯糖 (グラニュ糖)を蒸溜水に溶解して $100 \mathrm{ml}$ とし,
10\%砂糖液をその都度作成与る。（2）抗凝国剂 として $3.2 \%$ のエン酸ソーダまたは $0.1 \mathrm{M} の$ 蓚酸ソーダ 1 容に 9 容の新鮮血液をとる。抗凝 固剂としてへパリンまたは EDTA を用いるの は適当でなく，脱フィブリン血液も用いない方 がよい（3）上記の患者血液 1 容に対し10\%砂 桾液 9 容の割合で混和し, 室温 $\left(23^{\circ} \mathrm{C}\right)$ で 30 分 間放置する。（4）1, 500 回転10分間遠沈後上清 の溶血の有㫮を肉腿的に判定する.

2. Sucrose hemolysis test:(1) 蔗糖 (試薬) $92.4 \mathrm{~g}$ を $91 \mathrm{ml}$ の $50 \mathrm{mM} \mathrm{NaH} \mathrm{PO}_{4}$ 及び $9 \mathrm{ml}$ の $50 \mathrm{mM} \mathrm{Na} \mathrm{HPO}_{4}$ に溶解し, 苲溜水を加之一 $1,000 \mathrm{ml}$ と等張庶糖液を作成する。この溶液 は $5^{\circ} \mathrm{C} て ゙ ~ 1 \sim 2$ 週間は貯蔵しても使用し得る が，その都度作成する方が誤りが少ない（2） 等張蔗糖液 $0.85 \mathrm{ml}$ に $\mathrm{ABO}$ 適合の正常血清 $0.05 \mathrm{ml}$ を加えてよく混和与る。（3）これに 50 $\%$ 血球生食水浮遊液 $0.1 \mathrm{ml}$ 孝加觉て直りに混 和与る。 $50 \%$ 血球生食水浮遊液はクエン酸ン一 ダ添加血液を生食水で 3 回洗涤後 $50 \%$ の割合に 生食水に浮遊与るように調製する。（4)室温に て30分間放置後遠沈し，上清の溶血の有無を判 定する。（5)溶血を認める場合は正常血清々蔗 糖溶液の混液を zero blank, 反応系の全溶血を 100\%として溶血度をシアンメトへモグロビン 法により測定する。溶血度が $10 \%$ 以上が陽珄， 5 10\%が疑陽性，5\%以下が陰性である.

＜臨床的意義ならびに考察 >

本試験が PNH に特異的な検査法であること は諸家により報告されており，Hansen ${ }^{4)}$ は大量 の輸血を行なった PNH の 1 例で Ham の test 扣よび Crosbyの test が陰性でありながら Su- 
crose hemolysis test が弱陽性を示したことよ り，本試験は従来の検査方法より鋭敏であると 述べている。一方 Stratton 55) は免疫性溶血 性貧血, 慢性リンパ性白血病, 骨髄線維症など に本試験が陽性を示す例があるが，アルブミン 添加により溶血が阻止されるので鑑別し得ると 報告している.

本試験の手技は報告者により多少とも異なっ ているが，最近 Hartmann ら6) は種々検討を 行ない.PNH の診断に特異性の高い条件を報 告している。すなわち Sugar water test には (1)脱フィブリン血液を用いない.(2)抗凝固剂と してクェン酸ソーダまたは苳酸りーダを用い る。(3) $37^{\circ} \mathrm{C}$ に睬置するより室温 $\left(23^{\circ} \mathrm{C}\right)$ に放 置した方がよいまた(4)患者が貧血強度の場合 は PNH 以外の血球も溶血し易く, 輸血を頻回 に行なった際にはPNHでも陰性を示すことが あるので注意を要すると述べている.

Hansen ${ }^{4)}$ は PNH $の 7$ 例中 Sugar water test の陽性例は 3 例の久で，しかもこの3 例は常に 陽性を呈しなかったと報告しているぶ，Hartー mann 56) の成績をは(゙ぬ Sucrose hemolysis test が陽性例では常に Sugar water test も陽性 であるとの卸告が多い.

本侙験陽珄例の多くはPNH としての臨床症 状执よび検査所見を有するが，稀に再生不良性 負血の臨床像を示与症例がある。元来 PNH と 再生不良性貧血は全く別個の疾患之考えられて いたが，PNH の経過中骨䯣は低形成性となり， Pancytopenia を伴って再生不良性貧血と鑑別困 難な病像を呈することがある。近に初期には再 生不良性貧血の臨床像であった症例が後に血色 素尿を伴い, Sucrose hemolysis test, Ham の test が陽性となって PNH と誜断される場合が ある。Dacie は両疾患の関連について早くから 注目 ( ${ }^{7)}$, 最近 Aplastic anemia-PNH syndrome なる名称を提唱した8). 従って再生不良性貧血 の臨床にあたってはPNHを念頭に打き検索す る必要があろう。

本試験が Ham の test に此し有利な点は(1)
1 Sugar Water Test (簡健法:

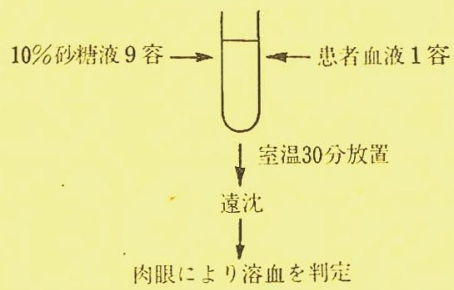

2 Sucrose Hemolysis Test

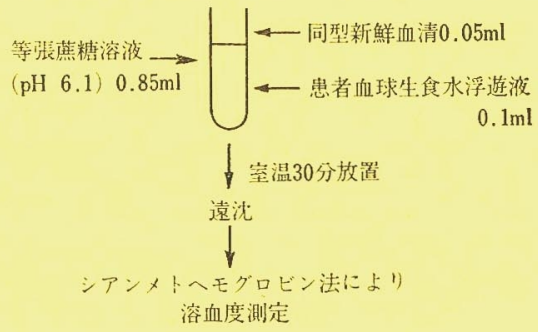

図 1 検查方法

手技が簡便であること，(2)血清の必要量が少な くて済さこと。(3) $37^{\circ} \mathrm{C}$ で躬置する必要がない こと, (4) PH の厳密な調整は必ずしも不必要で あることがあげられる。今後ルーチンの検査と して広く利用されることが期待される。

\section{参考文献}

1) Hartmann. R.C., and Jenkins, D.E., Jr.: New Eng. J. Med., 275; 155, 1966.

2) Rosse, W.F. and Dacie, J.V.: J. Clin. Invest., 45; 736, 1966.

3) Mollison, P.L. and Polley, M.J.: Nature, 203; 535, 1964.

4) Hansen, N.E.: Acta. Med. Scand., 184; 543, 1968.

5) Stratton, F., and Evans, D.I.K.: Brit. J. Haemat, 13; 862, 1967.

6) Hartmann, R.C., Jenkins, D.E., Jr. and Arnord, A.B.: Blood, 35; 462, 1970.

7) Dacie, J.V. and Giplin, A.: Arch. Dis. Child., 19; 155, 1944.

8) Lewis, S,M, and Dacie, J.V.: Brit. J. Haemat., 13; 236, 1967. 